\title{
DIGNIDADE, TRABALHO E ESCRAVIDÃO: A APRENDIZAGEM DOS OFÍCIOS MECÂNICOS NA AMÉRICA PORTUGUESA, SUAS CONSEQUÊNCIAS SOCIAIS E JURÍDICAS NA FORMAÇÃO DE UMA IDENTIDADE COLETIVA DOS TRABALHADORES
}

Augusto Eduardo Miranda Pinto

Possui mestrado em Educação Tecnológica pelo Centro Federal de Educação Tecnológica Celso Suckow da Fonseca, mestrado e doutorado em Direito pela Universidade do Estado do Rio de Janeiro. Atualmente é pós doutorando na Universidade de Coimbra no Centro de Direitos Humanos e professor do Instituto Federal Fluminense no curso de pós graduação stricto senso, professor e pesquisador da Universidade Estácio de Sá, Auditor Fiscal do Trabalho e Chefe do Setor de Inspeção do Trabalho - Gerência Regional do Trabalho de Cabo Frio-RJ. Tem experiência na área de Direito, com ênfase em Direito do Trabalho e Ambiental, atuando principalmente nos seguintes temas: meio ambiente do trabalho, urbanismo e direitos humanos.

\section{Resumo}

$\mathrm{O}$ artigo propóe analisar a formatação das corporaçóes de ofício que não ocorreu de maneira idêntica às congêneres ibéricas, guardando intensas diferenças em relação à realidade da metrópole, mas tendo papel fundamental na formação do trabalho dos ofícios mecânicos, com representação dos interesses dos artesãos. Apesar da ampliação do comércio, a vinda da Corte para o Brasil também abriu uma crise nas corporaçóes, em função das medidas liberalizantes introduzidas. Após sua extinção, suas funções assistenciais seriam substituídas pelas sociedades de auxílio mútuo, e mais tarde pelos sindicatos. Mas, essa transição rompeu uma rede de participação social existente, enfraquecendo a posição do cidadão perante o Estado, mas com uma representação política em face do poder local, de forma a defenderem seus interesses. Estabelece-se a percepção dentro desse espaço histórico, como um reflexo do contexto colonial do império português, no qual o papel do trabalhador mecânico repercute no seu grupo e acarreta uma ordem corporativa que forma uma teia com desdobramentos políticos e sociais. Neste processo há um conflito entre a atuação dos livres e dos escravos no exercício do ofício na rua, sendo necessário avaliar a complexidade no papel desses atores que participaram ativamente das mudanças econômicas e políticas sedimentadas na relação capital-trabalho, com a consolidação de 
uma formação coletiva dos trabalhadores e sua ascensão em uma sociedade extremamente estamentada, bem como seus reflexos na contemporaneidade.

\section{Palavras-chave}

Dignidade; Direitos Humanos; Corporações de Ofício; Direito do Trabalho.

\section{Abstract}

The article aims to analyze the formatting of the Guildas that doesn't occurred in the same way as the Iberian counterparts, keeping intense differences with the reality of the metropolis, but having a fundamental role in shaping the work of the mechanical trades, with the representation of the craftsman's interests. Despite the expansion of trade, the arrival of the Court to Brazil also opened a crisis in corporations, due to the introduction of the liberalizing measures. After their extinction, their assistance functions would be replaced by mutual aid societies, and later by the unions. But this transition broke an existing social network participation, weakening the position of the citizen to the state, but with a political representation in favor of the local government to defend their interests. The perception within this historical space is established as a reflection of the colonial context of the Portuguese empire, in which the role of mechanical worker resonates in his group and carries a corporate order to form a web with political and social developments. There is a conflict in this process between the activities of the free and the slave about doing their jobs on the street, being necessary to assess the complexity of the role of these people who participated actively in sedimented economic and political changes in the capital-labor ratio, with the consolidation of a collective training of workers and their rise in an extremely estamental society and its consequences nowadays.

\section{Key words}

Dignity; Human Rights; Guild; Labor Law.

\section{Introdução}

Desde o início da colonização na América Portuguesa esteve presente à organização do trabalho artesanal. Ela teve importância fundamental na política local das cidades, junto ao Senado e na Câmara, com desdobramentos sociais e econômicos significativos. Ainda no princípio, se necessitou de uma mão de obra especializada na colônia, tendo em vista o aumento dos núcleos populacionais e as necessidades de funçóes artesanais nas construçóes e atividades que se iniciavam, apostando-se no ingresso inclusive de escravos vindos da África e dos indígenas evangelizados pelos jesuítas. 
O regime de trabalho dos artesãos tem início ainda em Roma no tempo de Pompílio (715-672) A.C., em que havia o colégio dos artesãos. Os artífices prosperaram até seu declínio com a invasão dos bárbaros e a utilização do instituto da servidão. Retornaram paulatinamente no século X, com o aparecimento das corporaçóes, surgindo na Alemanha, depois na Inglaterra, e posteriormente na França, consistindo no aperfeiçoamento das associações anteriores, se dedicando ao comércio e as grandes obras em construção, com destaque as catedrais góticas e proporcionando um desenvolvimento econômico significativo. Ademais, havia entre suas funçóes o propósito de assistencialidade e uma rigorosa fiscalização do trabalho, com uma complexa hierarquização, que culminou no modelo do século XVI, onde para obter o título de mestre ter-se-ia que se submeter a custosos exames. ${ }^{1}$

As Câmaras portuguesas tinham uma forma de representação da classe trabalhadora efetuada através das corporaçóes de ofício. Eram eleitos pelos comerciantes e artesãos vinte e quatro representantes, no caso da cidade de Lisboa e Porto, formando a 'Casa dos Vinte e Quatro'; e doze nas demais. Segundo Lopes ${ }^{2}$ estes nomeavam dentre eles, quatro que seriam os procuradores dos 'mesteres' (mestres) e que teriam representação no Conselho Municipal. Boxer ${ }^{3}$ entendia que o número de procuradores eram quatro, e que tinham direito a comparecer a todas as reunióes do Conselho e a votar nas matérias que houvesse interesse das 'guildas'(como as corporaçóes de ofício eram denominadas) e também quanto à vida econômica da vila ou da cidade. Sua influência atingia inclusive a administração municipal, principalmente em função do apoio de Dom João I, mestre de Avis, desde 1383, à sua causa.

Dentro dessas votaçôes também eram avaliadas as questôes referentes às condiçôes de aprendizagem. As guildas eram compostas por bandeiras, que poderiam representar apenas um ofício ou vários, totalizando o total de doze, e estas indicariam dois membros para formar a 'Casa dos Vinte e Quatro'. O membro mais velho da referida 'Casa' ou dos doze do povo (quando no local náo havia a 'Casa', mas tinha representação corporativa) era chamado de 'juiz do povo' e como tal podia representar os interesses da classe trabalhadora no Senado, na Câmara e em Lisboa, perante até a própria Coroa. A incorporação dos juízes aumentava consideravelmente a importância política das corporaçóes na administração municipal. A eleição para a referida 'Casa' se dava somente com condiçóes específicas: os membros deveriam ter quarenta anos, serem casados, terem passado por todos os cargos da referida bandeira (do ofício que executavam) e que tivessem conseguido dois

1 GONÇALVES, Lopes. "As corporaçōes e as bandeiras de ofícios”. Revista do Instituto Histórico e Geográfico Brasileiro, vol. 206, janeiro-março. Rio de Janeiro: Departamento de Imprensa Nacional, 1952, 172.

2 GONÇALVES, Lopes. "As corporaçōes e as bandeiras de ofícios”. Revista do Instituto Histórico e Geográfico Brasileiro, vol. 206, janeiro-março. Rio de Janeiro: Departamento de Imprensa Nacional, 1952, 182.

3 BOXER, C. R. O império marítimo português: 1415: 1825. Lisboa: Ed. 70, 2012, p. 268. 
terços dos votos. Privilegiava-se a experiência e o apoio de seus pares. Aqueles que não exerciam a função de 'juiz do povo', desempenhavam importantes funçóes municipais com repercussão política e proveito lucrativo. ${ }^{4}$

Dom Manuel em 1499, em sua carta régia, ratificava em Lisboa os poderes dos 'mesteres' para dar voz pelo povo, como vemos a seguir.

Pelo que nos apontastes na maneira que se tem no dar das vozes em alguns ajuntamentos, que de necessidade ás vezes se fazerem por bem da governança da cidade, e em algumas outras coisas para que convém, hemos por bem e determinamos que nos tais ajuntamentos não haja mais vozes que as dos Vinte e Quatro dos mesteres, e isto no que toca aos do povo porque estes abastam por êle, e assim se cumpra. ${ }^{5}$

A instituição da 'Casa dos Vinte e Quatro' também houve no Brasil, embora sem essa denominação. Segundo Lopes Gonçalves, a primeira notícia que se tem referência das corporaçôes de ofício é de 21 de maio de 1641 com a eleição de doze mestres na Câmara Municipal de Salvador, os quais podiam eleger um 'juiz do povo’ e um escrivão. Podemos afirmar que se manteve a formação político-administrativa de representação das relaçóes de trabalho da Corte Portuguesa. Era uma Casa com metade dos 'mesteres' que a cidade de Lisboa e Porto, mas com igual número de membros que a cidade de Guimaráes, provavelmente em função dos poucos ofícios prestadores de serviços à época. ${ }^{6}$

Posição diversa de Vieira Fazenda, que afirma a inexistência da Casa dos Vinte e quatro no Brasil, mas reconhece que os representantes dos ofícios mecânicos eram ouvidos nos negócios importantes, sendo eleitos pelo povo e a Câmara, com juízes da terra ou pedâneos (o equivalente do 'juiz do povo da Casa dos Vinte e Quatro de Lisboa), três vereadores e um procurador. ${ }^{7}$

Evidentemente, a formatação das corporações de ofício não ocorreu de maneira idêntica às congêneres ibéricas, guardando intensas diferenças em relação à realidade da metrópole. Ressalta-se que uma das semelhanças é o papel delas na formação do trabalho dos ofícios mecânicos, com representação dos interesses dos artesãos frente à demanda por obras, que se ampliou, principalmente, com a vinda da familia real no século XVIII.

Apesar da ampliação do comércio, a vinda da Corte para o Brasil também abriu uma crise nas corporaçôes, em função das medidas liberalizantes introduzidas, como: a

4 GONÇALVES, Lopes. “As corporaçōes e as bandeiras de ofícios”. Revista do Instituto Histórico e Geográfico Brasileiro, vol. 206, janeiro-março. Rio de Janeiro: Departamento de Imprensa Nacional, 1952, 183.

5 GONÇALVES, Lopes. "As corporaçōes e as bandeiras de ofícios”. Revista do Instituto Histórico e Geográfico Brasileiro, vol. 206, janeiro-março. Rio de Janeiro: Departamento de Imprensa Nacional, 1952, 183.

6 GONÇALVES, Lopes. "As corporaçōes e as bandeiras de ofícios”. Revista do Instituto Histórico e Geográfico Brasileiro, vol. 206, janeiro-março. Rio de Janeiro: Departamento de Imprensa Nacional, $1952,187$.

7 LIMA, Heitor Ferreira. Formação industrial do Brasil: período colonial. Rio de Janeiro: Fundo de Cultura: 1961, p. 250. 
abertura dos portos e a liberdade da indústria, ambas ocorridas em 1808. Conforme a Constituição de 1824, no seu artigo 177, inciso 25 ocorreu à extinção das mesmas, e que viriam a ser substituídas, posteriormente, pelas sociedades de auxílio mútuo, e mais tarde pelos sindicatos, a partir de um processo de formação coletiva dos trabalhadores. Mas, essa transição rompeu uma rede de participação social existente, enfraquecendo a posição do cidadão perante o Estado, e de sua representação que era, com as devidas proporçóes, de uma classe que náo tinha acesso aos privilégios da corte ${ }^{8}$.

Os ofícios se organizaram atrelados aos interesses dos colonizadores portugueses, sendo adaptada a mesma hierarquia dos ofícios existentes nas corporaçóes da metrópole, estando os artesãos divididos em: aprendizes, oficiais e mestres. Um aprendiz precisava pelo menos quatro anos de prática para passar por um exame avaliador e adquirir junto ao escrivão do ofício uma carta que o habilitaria a exercer suas funçóes. O exercício desse labor teve uma organizaçáo significativa no Rio de janeiro, tendo em 1792: cento e três oficiais examinados, com lojas abertas trabalhando na cidade. Embora houvesse um controle pelo poder régio, havia também uma representação política em face do poder local, de forma a defenderem seus interesses, perante, inclusive, ao senado e a câmara, como anteriormente apresentado ${ }^{\text {? }}$.

Neste processo de representação há um conflito entre a atuação dos livres e dos cativos no exercício do ofício na rua, ocorrendo até prisóes em função da atividade ilícita de escravos, mulheres e pessoas imperitas. As corporaçóes exerciam assim um papel de proteção a seus associados, com auxílio econômico e controle sobre a produção e comércio na cidade, juntamente com as irmandades religiosas e ordens terceiras, que no Rio de Janeiro eram referência para os diversos ofícios mecânicos, oferecendo empréstimos e controlando a qualidade dos serviços, com regras severas quanto ao descumprimento. Exerciam, assim, um papel fiscalizatório das atividades manufatueiras e defendiam a atuação dos aprendizes e oficiais que estavam ligados à irmandade, em detrimento dos outros sem qualificação adequada ${ }^{10}$. Posteriormente com sua extinçáo, às irmandades e as associaçóes mutualistas continuariam com a função assistencialista que cabia às corporaçóes de ofício, mas sem o aspecto hierárquico e as condições rígidas de admissão para o ofício, em função da prova para os mestres e a partir da carta de aceite que era exigida.

Adam Smith exibiu uma oposição considerável quanto ao aprendizado nas oficinas. Apresentando os aprendizes como preguiçosos, argumentou contra o controle das

8 MARTINS, Mônica de Souza Nunes. Entre a cruz e o capital: as corporações de ofícios após a chegada da família real (1808-1824). Rio de Janeiro: Arquivo Geral da Cidade do Rio de Janeiro/Garamond, 2008, p. 5, 6 .

9 MARTINS, Mônica de Souza Nunes. "A arte das corporaçôes de ofícios: As irmandades e o trabalho no Rio de Janeiro Colonial.” In: CLIO-Revista de Pesquisa Histórica, Recife, n. 30.1, 2012, p. 10,11.

10 MARTINS, Mônica de Souza Nunes. "A arte das corporaçóes de ofícios: As irmandades e o trabalho no Rio de Janeiro Colonial." In: CLIO-Revista de Pesquisa Histórica, Recife, n. 30.1, 2012, p. 12,15. 
corporações nas atividades profissionais, em função do prejuízo pela falta de concorrência e do exercício de um monopólio prejudicial ao livre comércio. Suas ideias visavam uma total reformulação nas relaçóes de trabalho, de modo ao trabalhador poder escolher, independente das amarras das corporaçóes, onde, como e por quanto trabalhar. Evidente, que na prática, tais afirmaçóes não eram tão verossímeis, mas em um ambiente controlado por aprendizes e mestres, o autor apresentou suas ideias liberais com uma visão preconceituosa.

Um aprendiz tem tendência para ociosidade, e é quase sempre indolente, dado que não tem qualquer interesse imediato em não ser. Nos empregos inferiores, os frutos do trabalho constituem sua única recompensa. (...) Um jovem concebe natural aversão pelo trabalho de que durante muito tempo não obtém qualquer benefício ${ }^{11}$.

Thompson também critica a forma remuneratória dos artesãos firmando que seus salários eram no século XIX determinados por concepçóes de prestígio social e pelo 'costume', "em vez da oferta e procura do mercado de trabalho. A regulaçáo do salário usual podia envolver muitos fatores, desde o status determinado pela tradição para o artesão rural, até a intricada regulamentação institucional nos centros urbanos." 12

O crescimento do número de artesáos, da demanda pelos seus serviços, da quantidade de lojas e da enormidade de obras falsificadas preocupava as autoridades e as irmandades, que buscavam estratégias para unificar regras e exercer maior controle sobre o trabalho dos artífices na cidade. Por outro lado, os artesãos buscavam suas garantias de segurança profissional e econômica: no primeiro caso, queriam ter o controle sobre a produção de seus artigos, eliminando qualquer concorrência de artífices não ligados às irmandades; no segundo, buscava no auxílio mútuo a garantia necessária para as atribulações e incertezas da vida. Neste processo de crescimento e desenvolvimento urbano, as irmandades dos ofícios desempenharam um papel fundamental na organização da vida social, profissional e econômica na cidade. ${ }^{13}$

Podemos observar um monopólio de mercado pelas corporaçóes de ofício, que tinham seus salários regulados mais por costume do que pelas relaçóes de oferta e procura, mas apresentavam um produto de boa qualidade, principalmente pela valorização no meio artesanal da qualificação dos mestres e do compromisso com os consumidores de sua excelência na prestação de serviços.

11 SMITH, Adam. Inquérito sobre a natureza e as causas da riqueza das nações. Lisboa: Fundação Calouste Gulbenkein, 1993, vol. I, p. 270.

12 THOMPSON, E.P. Formação da Classe Operária Inglesa. 3 vols. Rio de Janeiro: Paz e Terra, 1987, p. 89.

13 MARTINS, Mônica de Souza Nunes. Entre a cruz e o capital: as corporaçóes de ofícios após a chegada da família real (1808-1824). Rio de Janeiro: Arquivo Geral da Cidade do Rio de Janeiro/Garamond, 2008, p. 74. 
No início do século XIX houve alteraçóes significativas neste sistema com o avanço das ideias liberais vindas da Europa e do fortalecimento do livre comércio. As corporaçóes de ofício com o controle sobre a produção, distribuição e controle de preços acabaram por perder seu fôlego e a ter seu término decretado na Constituição de 1824, deixando marcas significativas na falta de formação de mestres. $\mathrm{O}$ artesão, em meio a uma sociedade extremamente estamentada, gozava de prestígio junto às camadas populares e depois de sua extinção, mesmo havendo desprezo pelas atividades manuais, era uma das poucas chances de mobilidade social para mão de obra carente e escrava. ${ }^{14}$ Seu papel foi de certa forma continuado através das irmandades religiosas, que tiveram papel fundamental em uma atuação assistencialista e mutualista aos trabalhadores.

\section{Desenvolvimento}

Há poucas obras sobre classe operária anterior a 1885. Há mençôes às associações mutualistas, mas sem admitir o importante papel dessas experiências à condição de antecedentes do movimento operário, considerando apenas como uma espécie de "pré-história” da classe laboral, estabelecendo um marco de distinção em 1888, em fase dos preâmbulos de uma formação sindical. Os primeiros anos do século XX viram o surgimento de um novo tipo de organização operária, criadas para exercer funções de cunho sindicais: lutando por melhores salários, pela diminuição da jornada de trabalho e por condiçóes de trabalho mais dignas. Essas organizaçóes pareciam se contraporem às sociedades de socorros mútuos existentes, mas tinham aspectos semelhantes, com elementos significantes de continuidade presentes, referentes à dignidade do trabalho, à valorização do trabalho manual e, sobretudo, aos princípios do conceito de uma formação de classe, em relação, inclusive, as corporaçóes de ofício que antecederam as mesmas, proibidas pela Constituição de $1824^{15}$.

Parece improvável que as corporaçóes pudessem continuar a existir clandestinamente depois de sua proibição, já que a lei de 29 de outubro de 1823 voltou a proibir as sociedades secretas e punia gravemente os membros que funcionassem sem autorização escrita para tal. Acreditamos que parte de suas atribuiçóes acabaram por ser continuadas pelas associaçóes mutualistas ${ }^{16}$.

14 MARTINS, Mônica de Souza Nunes. "A arte das corporaçôes de ofícios: As irmandades e o trabalho no Rio de Janeiro Colonial.” In: CLIO-Revista de Pesquisa Histórica, Recife, n. 30.1, 2012, p. 16.

15 BATALHA, Cláudio H. M. "Sociedades e trabalhadores no Rio de Janeiro do século XIX: Algumas reflexóes em torno da formação da classe operária”. In: Cadernos AEL: Sociedades operárias e mutualismo. Campinas: UNICAMP/IFCH, v.6, n.10/11, 1999, p. 45-47.

16 BATALHA, Cláudio H. M. "Sociedades e trabalhadores no Rio de Janeiro do século XIX: Algumas reflexôes em torno da formação da classe operária”. In: Cadernos AEL: Sociedades operárias e mutualismo. Campinas: UNICAMP/IFCH, v.6, n.10/11, 1999, p. 49. 
Todavia, há diferenças quanto ao papel das corporaçóes e das irmandades, enquanto a primeira atendia os interesses profissionais de seus integrantes, a segunda, e de modo especial, as Misericórdias, encarregavam-se dos encargos assistenciais e espirituais. Isto não descaracteriza o caráter mutualista das corporaçóes, ou ainda, em muitos casos, a origem das confrarias nos ofícios, mas ressalta-se que uma não era sinônima da outra, apenas, talvez, as irmandades sejam a faceta religiosa das corporações. "Em síntese, as irmandades funcionaram como agentes de solidariedade grupal, congregando, simultaneamente, anseios comuns frente à religião e perplexidades frente à realidade social”.

A irmandade destacava-se como a base econômica de sustentação das corporaçóes e para o desempenho dos ofícios. Isto porque eram elas que organizavam toda a estrutura econômica ligada ao exercício profissional dos artífices, cuidando desde a autorização para a prática do ofício, através da concessão da carta de exame, até o preço dos produtos comercializados pelos artesãos. Assim, era a irmandade responsável por fiscalizar os ofícios, cuidando de todas as condiçôes para o exercício da mão-de-obra do artífice; cobrava joia dos mestres que possuíam loja aberta na cidade e puniam aqueles que não cumprissem suas obrigações; determinavam as regras para o exercício do ofício e para a admissão de aprendizes, através do estabelecimento de um compromisso ou regimento, que muitas vezes baseava-se nos princípios de suas congêneres europeias. ${ }^{17}$.

Não obstante o lapso temporal do término das corporaçóes de ofício e das primeiras sociedades de auxílios mútuos, alguns elementos de continuidade na prática desses dois tipos de organização são facilmente perceptíveis. Entre eles podemos apontar: a excessiva preocupaçáo quanto à qualificação profissional, bem como a um sistema de controle sobre o mercado de trabalho e a defesa profissional através de propostas de controle e proteção do mercado contra a concorrência, bem como a busca de colocação dos associados no mercado de trabalho. As corporaçóes buscando perpetuar os seus negócios tiveram papel fundamental na produção de bons artigos a preços baixos, sendo intimamente ligada ao caráter religioso, com influência no desenvolvimento do próprio mercado de consumo. ${ }^{18}$

Após 1824, é possível afirmar que as sociedades de socorros mútuos eram as únicas formas legalmente viáveis de organização para os trabalhadores manuais livres, e que além do socorro aos seus associados era intrínseco aos seus objetivos a defesa profissional, com a continuação dos princípios das corporaçôes anteriores, que foram extintas. Mas, aquelas

17 MARTINS, Mônica de Souza Nunes. Entre a cruz e o capital: as corporaçóes de ofícios após a chegada da família real (1808-1824). Rio de Janeiro: Arquivo Geral da Cidade do Rio de Janeiro/Garamond, 2008, p. 75.

18 MARTINS, Mônica de Souza Nunes. Entre a cruz e o capital: as corporações de ofícios após a chegada da família real (1808-1824). Rio de Janeiro: Arquivo Geral da Cidade do Rio de Janeiro/Garamond, 2008 , p. 21. 
não eram apenas continuação destas, havia uma caracterização maior quanto a defesa de determinadas condiçôes de trabalho e salário, que aproximava as sociedades de socorro mútuo das sociedades de resistência do século XX, que culminaria na formação de sindicatos com representação da coletividade de trabalhadores. Sem sombra de dúvida além da ruptura institucional e jurídica da corporação de ofício, há mudanças na ritualística que regem estas instituiçóes, as sociedades mutualistas perdem o aspecto religioso no discurso das práticas coletivas dos artesãos ${ }^{19}$.

Não me parece que o fator externo à vida das corporaçóes (a sua proibição pela Constituição de 1824) possa por si só explicar as mudanças no campo da cultura desses trabalhadores; é preciso buscar fatores internos. A linguagem das corporaçóes já não dava conta do mundo do trabalho em meados do século XIX. Além disso, há um processo de democratização nas sociedades operárias, com a junção dos mestres (únicos com direito à organização à época das corporaçóes), dos oficiais e até dos aprendizes numa mesma associação, democratização esta perceptível também no peso crescente que as assembleias de sócios desempenham, pelo menos estatutariamente, na vida associativa. Ressalta-se que este processo se observa na cidade do Rio de Janeiro e não pode ser generalizado para outras regióes onde há dinâmicas regionais diferenciadas, como é o caso de Goiás que no início do século XX ainda se encontrava irmandades e confrarias de artesãos e trabalhadores, assumindo em muitos casos funçôes assistenciais e mutualistas ${ }^{20}$.

É possível constatar a existência de diversas associaçóes no Rio de Janeiro, a Associação Tipográfica Fluminense, que foi uma das primeiras organizaçóes operárias surgidas no Brasil, fundada em 1853 e quando se transferiu para capital federal foi responsável pelo comando de greve em 1858. Neste ano ainda, foi fundada a Associação de Auxílio Mútuo dos Empregados da Tipografia Nacional e a Associação dos Socorros Mútuos, mais tarde, transformada em Liga Operária e posteriormente em 1884 foi fundada a União Beneficiente dos Operários da Construção Naval. Verificamos afastamento do caráter beneficente em 1880 quando os operários do Arsenal da Marinha da Corte fundaram o Corpo Coletivo da União Operária, que se intitulou 'Centro representativo da Classe' e não uma associação de beneficência, mas teve como um dos seus objetivos a concretizaçáo de um montepio, de modo a formar de maneira pioneira um seguro social, se apresentando como uma instituição intermediária entre o tipo mutualista puro, do modo das irmandades e corporaçôes apresentavam anteriormente, e o do tipo reivindicatório, lutando

19 BATALHA, Cláudio H. M. "Sociedades e trabalhadores no Rio de Janeiro do século XIX: Algumas reflexôes em torno da formação da classe operária”. In: Cadernos AEL: Sociedades operárias e mutualismo. Campinas: UNICAMP/IFCH, v.6, n.10/11, 1999, p. 50.

20 BATALHA, Cláudio H. M. "Sociedades e trabalhadores no Rio de Janeiro do século XIX: Algumas reflexôes em torno da formação da classe operária”. In: Cadernos AEL: Sociedades operárias e mutualismo. Campinas: UNICAMP/IFCH, v.6, n.10/11, 1999, p. 52, 53. 
pela aprovação do Decreto Legislativo n ${ }^{\circ}$ 9601, de 12-VI-1886 perante o parlamento e o Imperador, ao qual denominava: Augusto Protector da classe operária, demonstrando a importância desse segmento, nas relaçôes de poder. ${ }^{21}$

Ademais, ressalta-se que as associaçóes criaram uma estrutura garantidora da paz social e de harmonia política, em funçáo de sua crença no cristianismo social, no liberalismo e no solidarismo radical, abrigando os democratas mais ardorosos, os observadores sociais caridosos e ainda aqueles, que sonhavam com o Antigo Regime. Seu aspecto aglutinador permitiu entrelaçar as contradiçóes da nova sociedade, reestruturada pela revolução industrial, adequando o mundo do trabalho e a produção em suas várias vertentes de experimentação social, sonhando com um futuro melhor, abarcando os utopistas, reformadores e posteriormente até os teóricos do socialismo. Foi o embriáo do desenvolvimento sindical, mas também um fenômeno de massificação e especialização.

Mas o desenvolvimento paralelo das forças da produção e da democracia não a marginalizou? Náo correu ela o risco de ser, daí em diante, apenas um lugar de experimentaçáo para vontades sociais ainda mal exploradas ou mal assumidas pelas grandes maquinarias modernas da profissão, do sindicato, do partido e do Estado? Quando Dalou inscreveu a palavra no pé da estátua da República na praça da Nation (1899), e Waldeck-Rousseau a legalizou, a associação poderia renascer na política?(grifos nossos) ${ }^{22}$

Todavia, não se deve analisar a influência das irmandades religiosas somente em torno da defesa de seus membros, ela introduziu na relaçáo de trabalho conceitos importantes de religiosidade cristá, como a moral e ética na profissão e na busca da execução de serviços com qualidade e respeito ao comprador.

Ao analisar a escravidão brasileira no século XIX, houve um aumento considerável do tráfico escravo, mesmo depois do compromisso com a Inglaterra de aboli-lo desde 1830. Com isso, mesmo com a proibição de algumas irmandades de aceitar o aprendiz negro, estes exerceram o artesanato, como forma de ter uma ocupaçáo mais especializada e também como forma de angariar fundos para seu senhor, como um 'escravo de ganho'.

Este número aumenta depois de 1828, quando os poderes da Câmara já não exerciam o controle dos que ingressaram nas profissôes mecânicas e as corporações não exerciam mais controle rígido sobre a atividade, ou tinham mesmo desaparecido. Neste cenário a indústria estrangeira invade o mercado nacional, com a presença de artífices ingleses, franceses, italianos e alemães, coincidindo com introdução de instrumentação mecanizada inglesa e com a maior participação dos escravos nas tarefas de acabamento de edifícios,

21 RODRIGUES, José Albertino. Sindicato e Desenvolvimento no Brasil. São Paulo: Símbolo, 1979, p. 6-7.

22 RÉMOND, R. Por uma história politica. $2^{\circ}$ Ed. Rio de Janeiro: FGV, 2003, p. 118. 
móveis, ferragens, etc., assimilando as técnicas dos diversos ofícios e tornando-se rivais: brancos, escravos, alforriados, mestres, aprendizes e oficiais. ${ }^{23}$

O argumento de que a concorrência de escravos seria a responsável por uma concorrência desleal das organizaçóes de trabalhadores livres, talvez tenha alguma validade até os princípios do século XIX; mas seria menos significativo em meados do mesmo, quando, além de um decréscimo da escravidão urbana e dos escravos de ganho, há um crescimento das associaçóes mutualistas operárias, o que leva a crer no fortalecimento de uma identidade coletiva. Neste caso podemos observar que o período pré-1888 representa um processo formativo de classe, com reveses e acertos, em uma fenomenologia de formaçáo de consciência que se dá permanentemente até o início do século XX, com a consolidação do movimento sindical ${ }^{24}$.

Muitos autores consideram os escravos como uma classe, inclusive Marx, no Manifesto Comunista aponta classes antagônicas: como senhores e escravos, e em outros escritos esclarece que a definição de classe no capitalismo é diferente nas formaçóes sociais prévias. Ao analisarmos o processo produtivo na escravidão urbana, podemos concluir que os escravos náo constituíam propriamente uma classe. Temos principalmente na cidade do Rio de Janeiro, algumas heterogeneidades do trabalho escravo existindo entre os escravos de ganho, como: supervisores de negócios de seus senhores, caçadores, barbeiros e trabalhadores domésticos. Os estudos clássicos demonstram que a condição escrava era caracterizada pelo domínio que o senhor exerce sobre ele, mas, ainda que este domínio ocorre-se no período analisado, ele era mitigado pelas diversas formas em que o trabalho era exercido, com formas de poder e mando diferenciadas. Nesse contexto, havia várias classes de escravos, alguns com autonomia e outros sujeitos a um intenso sistema repressivo.

Podemos exemplificar este destoamento de uma classe específica escravista o "fato dos feitores e outros escravos "de elite" estarem ora do lado do sistema, ora liderando as revoltas contra ele (...). Este seria o atributo próprio, (...), da pequena burguesia, indecisa entre a aliança com a burguesia ou a solidariedade com o proletariado" ${ }^{25} \mathrm{~A}$ ideia de que existia um movimento único escravista é controverso. As revoltas, em muitos casos, envolviam muitos segmentos da população, os escravos se associavam a forros e a homens

23 FLEXOR, Maria Helena. Os ofícios mecânicos e o negro no espaço urbano de Salvador. In: CONGRESSO INTERNACIONAL DO BARROCO IBERO-AMERICANO, 3., 2006, Ouro Preto. Anais...Ouro Preto: (CD ROM) 2006.

24 BATALHA, Cláudio H. M. "Sociedades e trabalhadores no Rio de Janeiro do século XIX: Algumas reflexóes em torno da formação da classe operária”. In: Cadernos AEL: Sociedades operárias e mutualismo. Campinas: UNICAMP/IFCH, v.6, n.10/11, 1999, p. 62, 66.

25 ASSUNÇĀO M. R. A resistência escrava nas Américas: algumas considerações comparativas. Libby, D. C., \& Furtado, J. F. Trabalho livre, trabalho escravo: Brasil e Europa, séculos XVIII e XIX. São Paulo: Annablume, 2006, pg. 353. 
de cor livres nas muitas rebelióes, e eram acompanhados de pessoas conceituadas da sociedade local, com interesses acima do estritamente abolicionista. A maior rebelião escrava do país, a famosa 'Revolta das Mares', em Salvador em 1835, os libertos representavam apenas $38 \%$ dos insurretos presos, tendo a participação de muitos artesãos e comerciantes independentes, apresentando a constituição de aliança sociais e coerentes, quase sempre os escravos não estavam atuavam como uma classe coerente, mais se unindo a outras revoltas. ${ }^{26}$ As construçóes de classe nesse contexto variavam conforme a sociedade escravista, a construção de uma participação cidadá, com a inclusão dos homens de cor livres foi um processo lento, complexo e contraditório, assim como sua participação na atividade produtiva manufatureira urbana, mas que apresentou uma formatação inclusiva em alguns casos, que seria a semente da participação coletiva dos trabalhadores na formação dos sindicatos no século seguinte.

A história operária é parte da história social e possuem características específicas em comum, como salienta o autor abaixo:

A história operária é um assunto multifacetado, embora os níveis de realidade ou de análise formem um todo: trabalhadores e movimentos, bases e líderes, os níveis sócio-econômico, político, cultural, ideológico e 'histórico' - tanto no sentido de operarem num contexto dado pelo passado, quanto no sentido de que mudam ao longo do tempo em determinadas maneiras específicas. ${ }^{27}$

A classe trabalhadora em formação no Rio de Janeiro ao longo do século XIX, não poderia ser dissociada da experiência de vida e trabalho e do espaço de luta, no qual surge uma nova consciência de classe, com forças sociais antagônicas, que opunham senhores e escravos, mas com um espaço de emancipação dentro do contexto urbano. No início do século XIX o Rio de Janeiro teve uma importância político-administrativa como sede do poder central, tal crescimento econômico ocorreu principalmente em função da autonomia comercial em relação à metrópole, que possibilitou o surgimento de grandes fortunas: como atacadistas, importadores e exportadores, e em especial traficantes de escravos, com uma acumulação significativa de capital, mesmo antes da chegada da família real.

Há extrema dificuldade na composição da força de trabalho em 1821, a população total da cidade do Rio de Janeiro era de 112695 habitantes, sendo 55090 escravizados e 57605 livres. Em 1872, o número de escravizados cai para a casa de 48939, enquanto a

26 ASSUNÇÃO M. R. A resistência escrava nas Américas: algumas considerações comparativas. Libby, D. C., \& Furtado, J. F. Trabalho livre, trabalho escravo: Brasil e Europa, séculos XVIII e XIX. São Paulo: Annablume, 2006, pg. 354.

27 HOBSBAWM, Eric. Mundos do trabalho. Rio de Janeiro, Paz e Terra, 1987, p. 29-30. 
população da cidade cresce para 274972 , sendo 226033 habitantes livres ${ }^{28}$. Nesta situação o papel da máo de obra escrava foi essencial na atividade produtiva e de serviços urbanos. Um dos fatores significativos para tal alteração foi o peso do tráfico de africanos na formação da força de trabalho urbano.

Mal chegados, os negros logo assimilavam o que lhes ensinava. Transformando-se em ferreiros, carapinas, marceneiros, caldeireiros, oleiros, alambiqueiros, e até mesmo em estres de açúcar, sabendo o cozimento do mel, o "ponto” do caldo, a purga do açúcar. (...) Distribuído por várias atividades, carregador, doceiro, cozinheiro, alfaiate, sapateiro, ia ganhar para o dono a remuneração paga pelos seus serviços. Havia também os que se obrigavam a uma contribuição diária ou semanal fixa para o senhor. O que excedesse seriam deles. Eram as sobras com que iriam comprar, mais tarde a alforria. ${ }^{29}$

As proibições ao tráfico na primeira metade do século XIX, culminando com a efetiva vedação em 1850 levaram a um aumento significativo no preço dos escravos, o que acabou por culminar com a venda de cativos para a zona cafeeira, sendo os espaços laborais deixados, ocupados por homens livres. É evidente que o mercado de trabalho assalariado não é como o conhecemos na atualidade, havia uma demanda reprimida através da escravidão urbana, principalmente nos escravos de ganho, que eram treinados em ofícios especializados ou não, sendo oferecidos pelos seus senhores para o aluguel, ou ainda, o próprio escravo buscava serviços ocasionais pela cidade, em troca de uma remuneração monetária, cabendo ao escravo repassar ao senhor diária ou semanalmente uma determinada quantia. Estavam inseridos em relações monetárias apesar de serem propriedades de outro ${ }^{30}$. O que Ciro Cardoso chama de "brecha assalariada" na economia escravista urbana, e demonstra a complexidade desse modelo escravista e a proximidade entre o trabalho livre e escravo no meio urbano, como verificamos abaixo:

Eram trabalhadores formalmente assalariados na relação que mantinham com os indivíduos que requisitavam os seus serviços, recebendo um salário que lhes garantia a sobrevivência e, em alguns casos, a formação de um pecúlio que lhes possibilitava a compra de sua alforria. Entretanto, o reverso da medalha manifestava-se, pois, como escravos, eles mantinham uma relação 'coisificada' de propriedade, com os seus senhores sendo obrigados a lhes entregar uma quantia diária ou semanal, previamente fixada com base no seu nível de propriedade, com os seus senhores sendo

28 SOARES, Luiz Carlos. O 'povo de Cam' na capital do Brasil: a escravidão urbana no Rio de Janeiro do século XIX. Rio de Janeiro: Faperj; Letras. 2007, p. 40

29 VIANA FILHO, Luis. O Negro da Bahia. Rio: Jose Olimpio, 1946, p. 255.

30 MATTOS, Marcelo B. Escravizados e livres: experiências comuns na formação da classe trabalhadora carioca. Rio de Janeiro: Bom Tempo, 2008, p. 40-43. 
obrigados a lhes entregar uma quantia diária ou semanal, previamente fixada com base no seu nível de especialização profissional, na sua força, capacidade e destreza, e também nas condiçóes do mercado desse tipo de força de trabalho. ${ }^{31}$

No século XIX era marcante a presença dos escravos de ganho, esses desenvolviam trabalhos variados, tais como: comércio ambulante, transporte de cargas, serviços diversos, transportes de pessoas, despejos de dejetos etc. Havia também os operários, os marinheiros, os quitandeiros de loja, os barbeiros, os cirurgióes que trabalhavam sob o regime de ganho. Os escravos de ganho eram obrigados por seus senhores a desenvolver tais atividades e a pagar quinzenalmente ou mensalmente uma determinada quantia, quantia esta que, muitas vezes, garantiam o sustento dos senhores e suas famílias. Podem-se dividir as atividades desenvolvidas pelos escravos de ganho em dois grupos: de rua e de ofício. A categoria de rua era composta de práticas já citadas, tais como comércio, transporte de cargas e pessoas e as de ofício, em pequenos estabelecimentos manufatureiros e nas indústrias. Vale destacar que a mendicância e a prostituição também eram atividades dos cativos de ganho, porém a prostituição de cativas era proibida, mas tal prática era rentável para os senhores e frequentemente utilizada. ${ }^{32}$

Os escravos de ganho desenvolviam atividades que iam desde o comércio ambulante, até mesmo, o transporte de pessoas nos seus ombros, nos dias chuvosos, bem como, o trabalho dos 'tigres', que carregavam barris em suas cabeças, com dejetos das residências onde laboravam, que eram a noite atirados ao mar e que eventualmente escorriam sobre suas costas, daí a denominação. A maioria deles eram mandados à rua para entregar ao seu senhor uma determinada quantia previamente estabelecida, cujo excesso pertenceria ao escravo, e podia inclusive proporcionar sua alforria. Essa quantia podia também ser estabelecida semanalmente ou mensalmente. Essa relação subordinada podia proporcionar castigos, caso as metas estabelecidas não fosse cumpridas. Com as devidas proporções, esta relação tinha semelhanças a relação de emprego que seria estabelecida no século seguinte, com requisitos como subordinação, onerosidade, pessoalidade e habitualidade na prestação de serviço, com certo grau de liberdade do escravo, de modo, a inclusive, adquirir proventos para conseguir sua liberdade.

Com exceçáo dos escravos exclusivamente domésticos, praticamente todos os demais deslocavam-se constantemente pela cidade em funçáo das atividades que desempenhavam, passando grande parte do dia distantes do controle efetivo de seus senhores e senhoras. Eram por assim dizer “donos” de seu próprio tempo. Essa mobilidade física dos escravos pro-

31 SOARES, Luiz Carlos. Os escravos de ganho no Rio de Janeiro do século XIX. Revista Brasileira de História n. 16. São Paulo, ANPUH/Marco Zero, 1988, p.110.

32 Ibid 
piciava também a ampliação de seu mundo social. Neste constante ir e vir de casa ao trabalho, relacionavam-se com indivíduos de vários grupos sociais e de diferentes raças. Estreitavam-se seus laços efetivos com outros escravos, libertos ou livres. Mas, o auge dessa suposta "independência" parecia ser conferida por uma forma de trabalho escravo, ao que tudo indica, exclusiva do ambiente urbano, o sistema de ganho.(grifos nossos) ${ }^{33}$

Os escravos também tiveram papel fundamental na luta por melhores condiçóes de trabalho, através de movimentos grevistas, podemos citar a paralisação da Ponta D 'Areia, em 1857, em que a reivindicação parece ter sido a suspensão dos castigos corporais, também a dos escravos de ganho em Salvador em junho de 1857, que paralisaram a capital baiana durante uma semana, em protesto contra a instituição de uma taxa de matrícula para cada ganhador, bem como obrigava ao uso de chapa com o número de matrícula do trabalhador(sendo escravo ou livre), sendo o movimento vitorioso e acabando com fim da greve e da obrigatoriedade do uso da chapa ${ }^{34}$. No Rio de Janeiro podemos citar uma luta coletiva dos escravos de ganho em 1872, reivindicando o aumento do valor recebido para o transporte de carne-seca dos navios para a terra. Os empregadores tentaram acabar com o movimento paradista contratando trabalhadores brancos, o que gerou conflito físico contra os fura-greves, que acabou com a detenção de treze negros e cinco brancos ${ }^{35}$. Outro caso, seria a da fábrica de velas e sabão na Gamboa, em 6 de setembro de 1854, em função de um descontentamento diante da ameaça da venda dos escravos, que gerou 30 prisóes. ${ }^{36}$

Ademais, em 1846 podemos verificamos que havia a presença maciça de trabalhadores cativos em uma série de estabelecimentos industriais. No estabelecimento litográfico de Heaton\&Rensburg, todos os impressores eram escravos africanos. Em uma oficina de cobre eram empregados 15 trabalhadores escravos, incluindo o feitor, enquanto em uma outra do mesmo ramo, 20 escravos eram empregados, não se encontrando ali nenhuma pessoa branca a não ser a dos escriturários. Também em uma oficina de ferradura e sapatos que era comandada por um capuchinho, encontravam-se escravos trabalhando, podendo citar uma pedreira de Botafogo, que empregava mais de 200 escravos, e a existência de cativos produzindo cal de conchas coletadas no mar, nas ilhas da baía próximas da cidade. ${ }^{37}$

33 ALGRANTI, Leila M. Os ofícios urbanos e os escravos de ganho no Rio de Janeiro Colonial.(180981822) In: SZMRECSÁNYI, T(org.). História Econômica do Periodo Colonial. 2. ed. São Paulo: EDUSP, 2002, p. 200.

34 REIS, João José. De olho no canto: trabalho de rua no Bahia na véspera da abolição. Revista Afro-Ásia, Salvador, n. 24, 2000.

35 CRUZ, Maria Cecília Velasco e. Tradições Negras na Formação de um Sindicato: Sociedade de Resistência dos Trabalhadores em Trapiche e Café, Rio de Janeiro, 1905-1930. Revista Afro-Ásia, Salvador, n. 24, 2000, p. 268.

36 GOMES, Flávio dos Santos. Quilombos do Rio de Janeiro do século XIX. In: Gomes, Flavio e Reis, Joáo José(orgs). Liberdade por um fio: história dos quilombos no Brasil. São Paulo, Companhia das Letras, 1997, p. 66.

37 SOARES, Luiz Carlos. O 'povo de Cam' na capital do Brasil: a escravidáo urbana no Rio de Janeiro do século XIX. Rio de Janeiro: Faperj; Letras. 2007, pg. 152. 
Tais exemplos demonstram a interação social dos escravos com seus companheiros livres no ambiente de trabalho e uma relação de laços de solidariedade e participação coletiva na formação de um ideário de 'classe' trabalhista, que se consolidaria no século seguinte com os movimentos sindicais.

Os senhores muita das vezes pagavam para o ensino de ofício mecânico para seus escravos, de modo que pudessem oferecer seus serviços aos proprietários de oficinas, aos quais, os lucros auferidos, seriam revertidos aos seus proprietários. Ressalta-se que "o emprego de escravos em oficinas artesanais e manufaturas pressupunha que eles tivessem que conhecer razoavelmente os segredos dos ofícios mecânicos, principalmente naquelas primeiras, pois no processo artesanal cada trabalhador era responsável pela realização de todas as etapas necessárias à confecção de um determinado produto". ${ }^{38}$ Tal situação alterava um paradigma vigente a época, de que os escravos eram ignorantes e trabalhavam de má vontade, tendo uma baixa rentabilidade, pois em todos os ramos da atividade industrial existiam escravos trabalhando lado a lado com trabalhadores livres, demonstrando habilidade e perícia, sem a visão preconceituosa anteriormente exposta.

Até 1840 houve contrataçáo de máo de obra, predominantemente entre os trabalhadores escravos, como foi o caso de José Vieira Sarmento, que empregava 11 cativos, 9 deles alugados de terceiros, em sua fábrica de pente de tartaruga. Na Real Fábrica de Fiação de Algodão teve a contratação de 10 escravos no seu período de existência entre 1815 e 1818. Também conforme o grau de especialização havia a contratação de imigrantes portugueses como foi o caso da manufatura chapeleira de José Wamosy, que em 1835 contratava, entre livres e escravos, 40 operários. Ressalta-se que um dos motivos da predominância do trabalho escravo nas manufaturas industriais, ocorre, em grande parte, pela aversão da população brasileira de qualquer tipo de trabalho manual ou mecânico, "aversão essa originada nos próprios condicionamentos ideológicos da secular sociedade escravista, que criaram a ideia do trabalho como "coisa de negro cativo" ${ }^{39}$. Até mesmo as ferramentas de alguns mestres de ofício, quando era necessário caminhar pela rua, contratavam escravos de ganho para leva-las, demonstrando um estigma social quanto a exercer qualquer trabalho manual, por menor que fosse ${ }^{40}$.

Nesse contexto de escassez de mão de obra livre no trabalho industrial e mecânico possibilitou o surgimento de uma nova classe social, que compreendiam "pessoas que compravam escravos para o fim especial de instruí-los em n’alguma arte útil ou ofício,

38 SOARES, Luiz Carlos. O 'povo de Cam' na capital do Brasil: a escravidão urbana no Rio de Janeiro do século XIX. Rio de Janeiro: Faperj; Letras. 2007, pg. 147.

39 SOARES, Luiz Carlos. O 'povo de Cam' na capital do Brasil: a escravidão urbana no Rio de Janeiro do século XIX. Rio de Janeiro: Faperj; Letras. 2007, pg. 149.

40 LUCCOCK, John. Notas sobre o Rio de Janeiro e partes meridionais do Brasil. São Paulo: Edusp, 1975, p. 72-73. 
vendendo em seguida por preço elevado, ou alugando seus talentos e trabalhos". Existia uma questão de demanda na mão de obra especializada escrava. Após 1850, que adquirir escravos ficou excessivamente caro, os que tinham grande capacidade produtiva na manufatura industrial, eram permitidos por seus senhores que trabalhassem por conta própria, exigindo uma quantia diária ou semanal ${ }^{41}$.

A aprendizagem após o término das corporações de ofício ocorriam nos próprios estabelecimentos e manufaturas, onde os escravos aprendiam seus ofícios financiados por seus senhores. Este era a forma que os proprietários de indústria utilizavam para serem remunerados pelos conhecimentos técnicos fornecidos, esse método pode ser constatado através de anúncios no 'Jornal do Commercio' no Rio de Janeiro, que seguem:

Em 1832, um "atelier" de costura procurava por "uma crioula de 12 a 13 anos, que [quisesse] aprender a coser, a bordar, e outras muitas coisas pertencentes a costura". Em 1843, "uma senhora francesa" encarregava-se de "ensinar a cozer a uma preta” na Rua de Santo Antonio, 21. Em 1850, uma fábrica de charutos da Rua do Cemitério, 29, na Saúde, além de procurar por "oficiais de charuteiro tanto livres como escravos", também recebia "moleques para ensinar". 42

Após abolição do tráfico negreiro africano de 1850, houve uma considerável diminuição no número de escravos de ganho na cidade. $\mathrm{O}$ trabalho do negro era substituído pelo trabalho de imigrantes portugueses. Apesar da redução do número, os escravos de ganho continuaram a exercer suas atividades até a abolição da escravatura. Partindo do recenseamento de 1872, podemos dividir o trabalho dos escravos em categorias. A primeira era os "criados e jornaleiros", um total aproximado de 5.785 escravos (4.997 homens e 788 mulheres). Os "criados" eram escravos domésticos alugados a terceiros, não escravos de ganho. Já os “jornaleiros”, de “jornal” (salário), seriam os cativos de ganho. Não temos dados precisos para saber o quantitativo de "jornaleiros". Uma segunda categoria era dos "marítimos" (marinheiros, remadores e barqueiros), que eram escravos de ganho, em um total de 527 homens. Os pescadores era a terceira categoria de escravos de ganho, com um total de 174 homens. O recenseamento organizado em 1872 revela que 2.135 escravos de ganho, de sexo masculino, trabalhavam nas indústrias de madeira, metais, edificaçóes, pavimentação, vestuário, calçados, chapéus, couros e peles. Também existiam as "costureiras" (1.384 mulheres cativas), os "artistas" (trabalhadores das oficinas artesanais) e os cativos que eram 497 (494 homens e 3 mulheres). ${ }^{43}$

41 COARACY, Vivaldo. Memórias da Cidade do Rio de Janeiro. Rio de Janeiro: José Olympio, 1995, pg. 464.

42 SOARES, Luiz Carlos. O 'povo de Cam' na capital do Brasil: a escravidão urbana no Rio de Janeiro do século XIX. Rio de Janeiro: Faperj; Letras. 2007, pg. 151.

43 Ibid 
Por volta de 1850 se manifestou a tendência de substituição dos escravos de ganho pelos trabalhadores livres imigrantes. Esses trabalhadores provavelmente rejeitavam atividades que os nivelavam com os cativos, por isso a maior parte dos escravos de ganho foi empregada para o transporte de carga. Tal atividade era vital para a sociedade da época, pois um homem branco não carregava pacotes, pois isso era considerado desprezível. $\mathrm{O}$ trabalho dos escravos de ganho náo se limitava ao transporte de carga e ao comércio, como já mencionado, tínhamos também os barbeiros ambulantes, cocheiros e tocadores de realejo. Os barbeiros eram ambulantes e de lojas. Os de loja faziam serviços típicos de barbeiro, mas também eram exímios cirurgióes. Esses manejavam o bisturi, faziam aplicações de sanguessugas, arrancavam dentes, serviços esses prestados à população livre pobre e a escravos. Também existiam os babeiros-músicos, muito solicitados em festas religiosas. Os escravos de ganham também desenvolviam a atividade mais desprezível da época, os despejos de dejetos humanos. Esses eram denominados, como já citados, os tigres.

Os senhores de escravo de ganho eram profissionais liberais, políticos, oficiais militares, funcionários públicos, sacerdotes, grandes e pequenos comerciantes e até pescadores e alfaiates, porém, na grande maioria das vezes, os senhores não declaravam suas atividades, o que nos faz supor que muitos deles eram sustentados exclusivamente pelos escravos de ganho. Nesse contexto, com as devidas proporçóes e limitaçóes conceituais os escravos de ganho eram trabalhadores assalariados que se sustentavam e em alguns casos conseguiam juntar algum dinheiro que lhes permitia comprar a própria liberdade. A vida de um escravo de ganho não era fácil. Os processos criminais são uma boa fonte para demonstrar os conflitos, assassinatos, enfim, um pouco da dura realidade que os cercava. Os seus senhores nunca lhe davam oportunidade de uma vida tranquila. Eram, muitas vezes, obrigados a recorrer até mesmo a meios desonestos e criminosos para obterem o dinheiro necessário a sua sobrevivência e ao pagamento dos seus senhores. ${ }^{44}$

Nesta contradição do sistema econômico do escravo de ganho e o trabalhador livre, há situação de vantagens para os escravos que podiam aumentar sua autonomia e ainda poder contribuir para conseguir sua liberdade, mas o sistema escravista era dominante e principalmente os poderes que detinham seus senhores. Como já citado, mesmo entre homens livres não havia um típico mercado de trabalho como na atualidade, porque o preço da mão de obra sofria consequências da presença escrava no meio urbano, "podemos afirmar que, enquanto o peso da escravidão urbana foi elevado, a variação salarial dos trabalhadores livres não se pautava apenas pelos critérios clássicos de oferta e procura de mão de obra proletarizada." ${ }^{45}$

44 Ibid

45 MATTOS, Marcelo B. Escravizados e livres: experiências comuns na formação da classe trabalhadora carioca. Rio de Janeiro: Bom Tempo, 2008, p. 46. 
O trabalho dos livres e cativos lado a lado, compartilhando as mesmas ocupaçóes e buscando os mesmos clientes levou a certas rivalidades. Mas, também proporcionou variadas formas de solidariedade, Karash comenta que os carregadores de café na zona portuária se organizavam para comprar a sua liberdade, "depois de fazer um sorteio para determinar quem seria libertado primeiro, trabalhavam pela liberdade de todos, permanecendo juntos até que todos fossem alforriados. O esforço do grupo era necessário para a sobrevivência". ${ }^{46}$

Há documentação comprobatória que os artesóes buscavam participação política dos lugares que atuavam, com importância fundamental na configuração do tecido social e na atividade econômica na vida dos aglomerados urbanos e suas adjacências rurais. Este trabalho visa, conforme a visão de Edward P.Thompson que considera a classe como uma formação sócio histórica, vislumbrar essa coletividade de artífices como formadora das relaçóes de trabalho, com impacto significativo nas manifestações das sociabilidades emergentes $^{47}$.

Nessa conjuntura do século XIX há necessidade de irmos além da dicotomia entre escravidão e liberdade, que nos tem sido apresentada como predominante no período imperial brasileiro, e nos defrontarmos a explorar os diferentes graus de liberdade e de participação das relaçóes de trabalho no 'locus' urbano, que permeou este período e fortaleceu uma consciência de classe laboral, sendo base para a formação do ideário sindical do início do século XX. Por outro lado, ainda temos exploraçóes nas condiçóes do trabalho que se mantem até a atualidade, como no caso do Distrito Federal, a despeito do decreto n. 1313 de 1891 que proibia o trabalho infantil na industrial têxtil, havia crianças trabalhando com menos de 18 anos, inclusive como aprendizes em oficinas a fim de aprender um ofício, onde muitas vezes, tinham que exercer tarefas penosas e carregar objetos pesados, bem como, castigos físicos eram práticas correntes no local do trabalho e estavam associados também a aprendizagem, tanto na educação formal como profissional ${ }^{48}$.

Neste processo de aprendizagem, mesmo depois do término das corporaçóes de ofício e da abolição da escravatura, a qualificação era decisiva para definir uma mobilidade geográfica e social, principalmente em busca de melhores salários o que não ocorria com os desqualificados. A necessidade de uma aprendizagem profissional não terminou com a visão liberal do século XIX, os empregadores necessitavam de empregar substitutos,

46 KARASCH, Mary. A vida dos Escravos no Rio de Janeiro (1808 - 1850). (1a ed.: 1987; trad.port.) Săo Paulo, Cia. das Letras, 2000.

47 MENESES. J. Artes Fabris e Ofícios Banais: o controle dos ofícios mecânicos pelas Câmaras de Lisboa e das Vilas de Minas Gerais(1750-1808).1. ed. Belo Horizonte: Fino Traço, 2013, p. 26.

48 BATALHA, Claudio. Limites da liberdade: Trabalhadores, relaçóes de trabalho e cidadania durante a primeira república. In: $L I B B Y$, D. C., \& FURTADO, J. F. Trabalho livre, trabalho escravo: Brasil e Europa, séculos XVIII e XIX. São Paulo: Annablume, 2006, pg. 100-101. 
em ofícios que longos períodos de aprendizado eram necessários para formar um oficial artífice e o próprio Mestre. As pequenas oficinas, essenciais para o funcionamento da economia, não tinham poder de pressão de modo a usar a força policial para reprimir os trabalhadores, daí negociavam melhores salários, regularidade e estabilidade no emprego, condiçóes de moradia, proteção legal e saúde, demonstrando a importância da qualificação através da aprendizagem, inclusive para a mobilidade social. ${ }^{49}$

A aprendizagem na segunda metade dos setecentos e nos primeiros anos do século XIX proporcionou um saber prático eficiente, capaz de responder as necessidades de uma sociedade que se fundada em uma recente economia diversificada com um mercado nascente, já complexo e dinâmico. Estabelece-se a percepção dentro desse espaço histórico, como reflexo do contexto colonial do império português, no qual o papel do trabalhador mecânico repercute no seu grupo social e acarreta uma ordem corporativa que forma uma teia com desdobramentos políticos e sociais.

Ademais, há significativa influência oitocentista do império português na aprendizagem moderna, perante o ordenamento jurídico brasileiro. Com o advento da Lei n. 10097, de 19.12.2000, que versa sobre o novo contrato de aprendizagem, alterou-se toda a sistemática do mesmo, absorvendo regras sobre aprendizagem profissional do menor, que antes eram tratadas por institutos jurídicos diferentes, compatibilizando, assim, normas do Estatuto da Criança e do Adolescente e da Constituição Federal Brasileira. Essa nova formatação previu a formação técnico-profissional caracterizando atividades teóricas e práticas, desenvolvidas metodologicamente e em tarefas de complexidade progressiva com incremento no ambiente de trabalho.

Com a regulamentação do decreto de no 5.598, de $1^{\circ}$ de dezembro de 2005, tais diretrizes foram mantidas e ampliadas levando a idade máxima para vinte e quatro anos, e a partir daí o programa se transformou em um processo intenso de inserção social. Nesta data havia 50 mil aprendizes no mercado de trabalho; e, em 2013, esse número já atingiu 340 mil aprendizes, conforme dados da coordenação de aprendizagem do Ministério do Trabalho e Emprego.

Atendendo a Recomendação no 117 da OIT, de 1962, que "a formação não é um fim em si mesma, senão meio de desenvolver as aptidóes profissionais de uma pessoa, levando em consideração as possibilidades de emprego e visando ainda a permitir-lhe fazer uso de suas potencialidades como melhor convenha a seus interesses e aos da comunidade", o programa de aprendizagem brasileiro não se apresenta como um instituto novo, mas desde a época oitocentista vem se caracterizando como palco de relaçôes laborais que

49 BATALHA, Claudio. Limites da liberdade: Trabalhadores, relaçôes de trabalho e cidadania durante a primeira república. In: $L I B B Y$, D. C., \& FURTADO, J. F. Trabalho livre, trabalho escravo: Brasil e Europa, séculos XVIII e XIX. Sáo Paulo: Annablume, 2006, pg. 103. 
representam uma força simbólica de concretização da participação dos trabalhadores e de sua inserção com maior dignidade no mundo do trabalho.

\section{Conclusões}

As corporaçóes de ofício no Brasil não se formaram de maneira idêntica às congêneres ibéricas, mas tiveram papel primordial na formação do trabalho dos ofícios mecânicos. Com o avanço das ideias liberais vindas da Europa e do fortalecimento do livre comércio, o controle sobre a produção, distribuição e controle de preços pelas corporaçóes de ofício acabaram por perder seu fôlego e culminaram no seu término decretado na Constituição de 1824, deixando marcas significativas na falta de formação de seus mestres.

Neste processo de representação as irmandades religiosas continuariam com a função assistencialista que cabia às corporaçôes de ofício, mas sem o aspecto hierárquico e as condições rígidas de admissão para o ofício, exercendo um papel fiscalizatório das atividades manufatueiras e defendendo a atuação dos aprendizes e oficiais que eram ligados à irmandade, em detrimento dos outros sem qualificação adequada.

O papel das corporaçóes de ofício já não dava conta do mundo do trabalho em meados do século XIX, mas, o papel do artesão ainda se fazia presente, e após extinção das corporaçóes, houve um processo de democratização nas sociedades operárias, com a junção dos mestres, dos oficiais e até dos aprendizes numa mesma associação, em um processo de democratização e representação na vida associativa. $\mathrm{O}$ artesão em meio a uma sociedade extremamente estamentada, gozava de prestígio junto às camadas populares, e era uma das poucas chances de mobilidade social para máo de obra carente e escrava. Seu papel foi de certa forma continuado através das irmandades religiosas e das associaçóes que desenvolveram uma estrutura garantidora da paz social e de harmonia política, em função de sua crença no cristianismo social, no liberalismo e no solidarismo entre os seus membros, valorizando conceitos importantes de religiosidade cristã, como a moral e ética na relação de trabalho e na busca da execução de serviços com qualidade e respeito ao comprador. Foi o embrião do desenvolvimento sindical, permitindo a transiçáo para uma nova sociedade restruturada pela revolução industrial, que alterou o mundo do trabalho e a produção, em vários aspectos de experimentação social.

Os escravos também participaram das atividades dos ofícios mecânicos, exercendo o artesanato ou o próprio comércio ambulante, como forma de angariar fundos para seu senhor, como escravo de ganho. Sua atividade era efetuada na rua, onde era exigida uma prestação de contas a seu senhor, em função de uma determinada quantia previamente estabelecida, cujo excesso pertenceria ao escravo, tal relação proporcionava certo grau de autonomia ao escravo, com controle de seu tempo e produção, de modo, a inclusive, adquirir proventos para conseguir sua liberdade. 
O aumento da produção em 1828 fez conviver em um Rio de Janeiro urbano, tanto os artífices ingleses, franceses, italianos e alemáes com seus rivais brancos, escravos, alforriados, mestres, aprendizes e oficiais, todos sem o controle rígido das corporaçóes já extintas. É evidente que ocorreram conflitos entre classes tão divergentes, principalmente em decorrência da concorrência desleal dos escravos em relação às organizaçóes de trabalhadores livres, mas, também proporcionou variadas formas de solidariedade, e estas diferenças seriam menos significativas em meados do século XIX, quando, além do decréscimo da escravidão urbana e dos escravos de ganho, há um crescimento das associaçôes mutualistas operárias, o que leva a crer no fortalecimento de uma identidade coletiva, que culminaria em um processo fenomenológico de formação de consciência, que no início do século XX consolidaria o movimento sindical.

O processo de aprendizagem, mesmo depois do término das corporaçóes de ofício e da abolição da escravatura, teve importância fundamental na mobilidade geográfica e social. Em uma sociedade estamentada, sem condições de acesso a educação ou a cargos públicos, em que se dependia de conhecimento político para ascende-los, aprender um ofício era oportunidade única para a população carente ou escrava.

Nesse contexto a aprendizagem moderna procura cumprir seu papel de inclusão social a partir da exigência legal do cumprimento de cotas nas empresas de maneira compulsória. A Lei n. 10097, de 19.12.2000, regulamentada pelo decreto de no 5.598, de $1^{\circ}$ de dezembro de 2005, aumentou consideravelmente a inserção de jovens no mercado de trabalho, muitas vezes de comunidades carentes, que mantem o caráter insertivo dos jovens sem oportunidades de emprego e que tem nesta oportunidade quebrar o determinismo que sua situação social o colocou, proporcionando trabalho digno e a esperança de um futuro melhor.

\section{Referências}

ALGRANTI, Leila M. Os ofícios urbanos e os escravos de ganho no Rio de Janeiro Colonial.(18098-1822) In: SZMRECSÁNYI, T(org.). História Econômica do Período Colonial. 2. ed. São Paulo: EDUSP, 2002.

ASSUNÇÃO M. R. A resistência escrava nas Américas: algumas consideraçôes comparativas. Libby, D. C., \& Furtado, J. F. Trabalho livre, trabalho escravo: Brasil e Europa, séculos XVIII e XIX. São Paulo: Annablume, 2006.

BATALHA, Cláudio H. M. Sociedades e trabalhadores no Rio de Janeiro do século XIX: Algumas reflexôes em torno da formação da classe operária. In: Cadernos AEL: Sociedades operárias e mutualismo. Campinas: UNICAMP/IFCH, v.6, n.10/11, 1999 . 
. Limites da liberdade: Trabalhadores, relaçôes de trabalho e cidadania durante a primeira república. In: LIBBY, D. C., \& FURTADO, J. F. Trabalho livre, trabalho escravo: Brasil e Europa, séculos XVIII e XIX. São Paulo: Annablume, 2006.

BONFIM CASSAR, Vólia. Direito do Trabalho. Niterói: Impetus, 2014.

BOSCHI, Caio César. Os leigos e o poder: irmandades leigas e política colonizadora em Minas Gerais. São Paulo: Ática, 1986.

BOXER, C. R. O império maritimo português: 1415- 1825. Lisboa: Ed. 70, 2012.

CUNHA, Luiz Antônio. O ensino de ofícios artesanais e manufatureiros no Brasil escravocrata. 2a ed. São Paulo: UNESP; Brasília, DF: FLACSO, 2005.

CRUZ, Maria Cecília Velasco e. Tradiçóes Negras na Formação de um Sindicato: Sociedade de Resistência dos Trabalhadores em Trapiche e Café, Rio de Janeiro, 19051930. Revista Afro-Ásia, Salvador, n. 24, 2000.

DELGADO, Mauricio Godim. Curso de direito do trabalho. Ltr, 2014.

FARIAS, Mônica Ferreira de. Aprendizes do ofício: profissionalização e reprodução familiar. Dissertação de mestrado em Sociologia. Rio de Janeiro: UFRJ/IFCS/Departamento de Sociologia, 1997.

FAZENDA, José Vieira. Antiqualhas e memórias do Rio de Janeiro, As bandeiras dos ofícios. Revista do IHGB, t. 86, v. 140.

FILHO, Adolfo Morales de Los Rios. O Rio de Janeiro imperial. 2a ed. Rio de Janeiro: Topbooks/UNIVER CIDADE, 2000.

FLEXOR, Maria Helena. Os oficios mecânicos e o negro no espaço urbano de Salvador. In: CONGRESSO INTERNACIONAL DO BARROCO IBERO-AMERICANO, 2006, Ouro Preto. Anais. Ouro Preto: (CD ROM), 2006.

GOMES, Flávio dos Santos. Quilombos do Rio de Janeiro do século XIX. In: Gomes, Flavio e Reis, João José (orgs). Liberdade por um fio: história dos quilombos no Brasil. São Paulo, Companhia das Letras, 1997.

GONÇALVES, Lopes. As corporações e as bandeiras de ofícios. Revista do Instituto Histórico e Geográfico Brasileiro, vol. 206, janeiro-março. Rio de Janeiro: Departamento de Imprensa Nacional, 1952.

HOBSBAWN, Eric. Mundos do trabalho: novos estudos sobre a história operária. 3a ed. Rio de Janeiro: Paz e Terra, 2000.

. Os trabalhadores: estudos sobre a história do operariado. 2a ed. São Paulo: Paz e Terra, 2000.

. et alii. Capitalismo transição. Rio de Janeiro: Eldorado, 1974. 
HOLANDA, Sérgio Buarque de (org.). A herança colonial - sua desagregação. In: História geral da civilização brasileira, tomo II, vol.1, 5a ed. São Paulo: DIFEL, 1982. . Raízes do Brasil. 26a ed. São Paulo: Companhia das Letras, 1995.

KARASCH, Mary. A vida dos escravos no Rio de Janeiro: 1808-1850. São Paulo: Companhia das Letras, 2001.

LE GOFF, Jacques. Mercadores e banqueiros na Idade Média. São Paulo: Martins Fontes, 1991.

. Os Intelectuais na Idade Média. Lisboa: Gradiva, 1983.

LEITE, Serafim. Artes e oficios dos jesuitas no Brasil (1549-1760). Lisboa, Rio de Janeiro: Brotéria, Livros de Portugal, 1953.

LIMA, Heitor Ferreira. Formação industrial do Brasil: período colonial. Rio de Janeiro: Fundo de Cultura: 1961.

. História do pensamento econômico no Brasil. 2a ed. São Paulo: Nacional, 1978. (Brasiliana; v. 360).

LOPEZ, Robert S. A revolução comercial da Idade Média 950-1350. Lisboa: Presença, 1976.

MANRICH, Nelson. Inspeção do Trabalho. São Paulo: LTr, 1991.

MARTINS, Mônica de Souza Nunes. Entre a cruz e o capital: as corporaçóes de ofícios após a chegada da família real (1808-1824). Rio de Janeiro: Arquivo Geral da Cidade do Rio de Janeiro/Garamond, 2008.

MATTOS, Marcelo B. Escravizados e livres: experiências comuns na formação da classe trabalhadora carioca. Rio de Janeiro: Bom Tempo, 2008.

MENESES. J. Artes Fabris e Ofícios Banais: o controle dos ofícios mecânicos pelas Câmaras de Lisboa e das Vilas de Minas Gerais (1750-1808),1. ed. Belo Horizonte: Fino Traço, 2001.

MORAES, Evaristo. Apontamentos de direito operário. São Paulo: LTr, 1971.

REIS, João José. De olho no canto: trabalho de rua no Bahia na véspera da abolição. Revista Afro-Ásia, Salvador, n. 24, 2000.

RÉMOND, R. Por uma história política. $2^{\circ}$ Ed. Rio de Janeiro: FGV, 2003.

ROCHA, Antonio Penalves (org.). José da Silva Lisboa, visconde de Cairu. São Paulo: 34, 2001.

RODRIGUES, José Albertino. Sindicato e Desenvolvimento no Brasil. São Paulo: Símbolo, 1979. 
ROTHSCHILD, Emma. Sentimentos econômicos: Adam Smith, Condorcet e o Iluminismo. Rio de Janeiro: Record, 2003.

RUSSELL-WOOD, AJ.R. Escravos e libertos no Brasil colonial. Rio de Janeiro: Civilização Brasileira, 2005.

RUSSOMANO, Mozart. O empregado e o empregador no direito brasileiro. Rio de Janeiro: Forense, 1984.

SACARANO, Julita. Devoção e escravidão: a Irmandade de Nossa Senhora do Rosário dos Pretos no Distrito Diamantino no século XVIII. 2a ed. São Paulo: Cia Nacional, 1978, v. 357.

SENNET, Richard. O artifice. São Paulo: Record, 2009.

SMITH, Adam. Inquérito sobre a natureza e as causas da riqueza das naçôes. $2^{a}$ ed. Lisboa: Fundação Calouste Gulbenkein, 1993, vol. I.

SOARES, Luiz Carlos. Os escravos de ganho no Rio de Janeiro do século XIX. Revista Brasileira de História, n. 16. São Paulo: ANPUH/Marco Zero, 1988.

. O 'povo de Cam' na capital do Brasil: a escravidáo urbana no Rio de Janeiro do século XIX. Rio de Janeiro: Faperj; Letras. 2007.

THOMPSON, E.P. Formação da Classe Operária Inglesa. 3 vols. Rio de Janeiro: Paz e Terra, 1987.

VIANA FILHO, Luis. O Negro da Bahia. Rio: Jose Olimpio, 1946. 